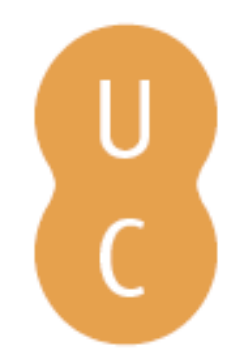

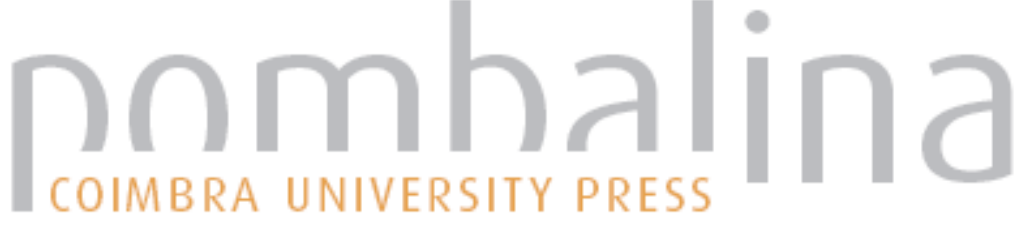

\section{Enquadramento histórico do romance em Roma}

Autor(es): $\quad$ Pimentel, Maria Cristina de Castro-Maia de Sousa

Publicado por: Centro de Estudos Clássicos e Humanísticos

URL

persistente:

URI:http://hdl.handle.net/10316.2/39248

DOI:

DOI:http://dx.doi.org/10.14195/978-989-26-1229-4_6

Accessed : $\quad$ 26-Apr-2023 11:29:11

A navegação consulta e descarregamento dos títulos inseridos nas Bibliotecas Digitais UC Digitalis, UC Pombalina e UC Impactum, pressupõem a aceitação plena e sem reservas dos Termos e Condições de Uso destas Bibliotecas Digitais, disponíveis em https://digitalis.uc.pt/pt-pt/termos.

Conforme exposto nos referidos Termos e Condições de Uso, o descarregamento de títulos de acesso restrito requer uma licença válida de autorização devendo o utilizador aceder ao(s) documento(s) a partir de um endereço de IP da instituição detentora da supramencionada licença.

Ao utilizador é apenas permitido o descarregamento para uso pessoal, pelo que o emprego do(s) título(s) descarregado(s) para outro fim, designadamente comercial, carece de autorização do respetivo autor ou editor da obra.

Na medida em que todas as obras da UC Digitalis se encontram protegidas pelo Código do Direito de Autor e Direitos Conexos e demais legislação aplicável, toda a cópia, parcial ou total, deste documento, nos casos em que é legalmente admitida, deverá conter ou fazer-se acompanhar por este aviso. 
FRANCISCO DE OLIVEIRA

PAOLO FEDELI

DELFIM LEÃO

Coordenadores

\section{- ROMANCE ANTIGO ORIGENS DE UM GÉNERO LITERÁRIO}

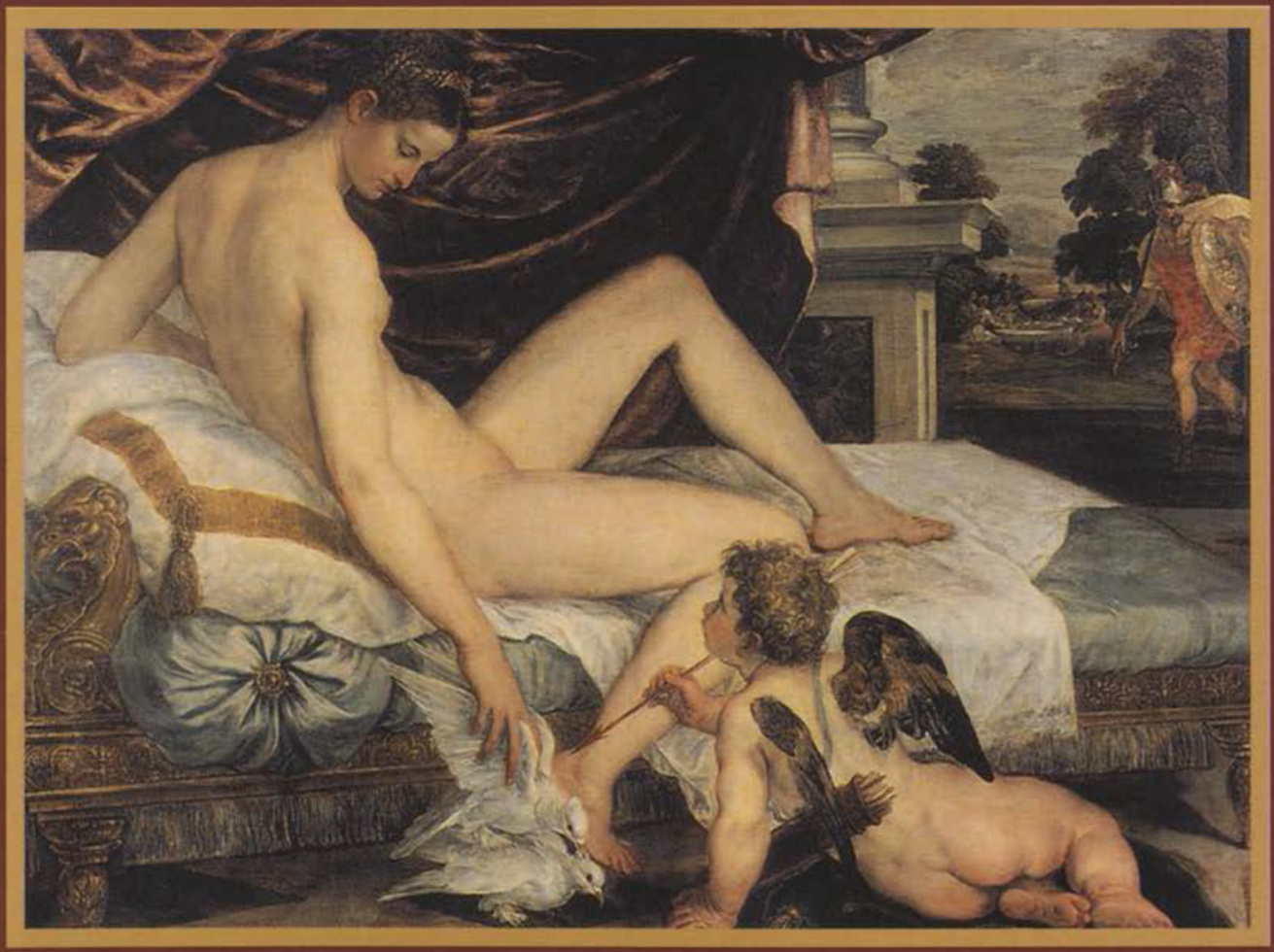

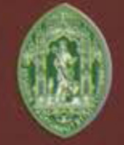

Universidade de Coimbra

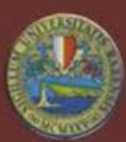

Università degli Studi di Bari

COIMBRA

2005 


\title{
ENQUADRAMENTO HISTÓRICO DO ROMANCE EM ROMA
}

\author{
Maria Cristina de CASTRO-MAia de Sousa Pimentel \\ Universidade de Lisboa
}

\begin{abstract}
Résumé: Considérant comme établi que le Satyricon est une oeuvre composée dans les temps néroniens, on dégage les coordonnées culturelles et historiques qui ont donné lieu à la création du roman en langue latine, et du roman de Pétrone en particulier. On essaie aussi de répondre à d'autres questions: les lecteurs du Satyricon, qui étaient-ils? Pouvaient-ils comprendre et apprécier, à cette époque et sous le régime du principat, ce roman extraordinaire? Pourquoi et comment a-t-on lu le Satyricon?
\end{abstract}

O século I d.C. é, sem dúvida, um século fascinante. Porque nele coexistem a luta sem tréguas por uma vida moral irrepreensível e um afundar-se complacente e prazenteiro nos mais prosaicos gostos e na mais servil devassidão.

É o século do homem em plena adesão aos poderosos, ou, às vezes com contornos de vil conivência, em forçado aplauso dos que mandam. Mas também é o século dos que, pela voz ou no silêncio, se opõem e são esmagados, na terrível crueldade que não lhes derruba todavia a dignidade.

É o século das maiores contradições e dos extremos dolorosos, século de Lucano, primeiramente amigo e companheiro de Nero, em seguida estóico e opositor ao tirano, por fim, na iminência da morte, filho que denuncia a própria mãe para tentar salvar a vida. ${ }^{1} \mathrm{E}$, se cedermos ao simbolismo de certas circunstâncias, não podemos deixar de reflectir - lendo Tácito ${ }^{2}$ - sobre o facto de Séneca, Lucano e Petrónio terem tido o mesmo fim e por idênticos motivos, ainda que a

\footnotetext{
${ }^{1}$ Tac., Ann. 15. 56. 4.

${ }^{2}$ Tac., Ann. 15. 60. 2 - 64 (Séneca); 15. 70. 1 (Lucano); 16. 19 (Petrónio).
} 
forma como acolheram e se comportaram perante a necessitas ultima tenha sido radicalmente diferente.

O século I é aquele em que os senhores se tornam escravos, nem que seja dos seus uitia, e os escravos se transformam em senhores, seja porque escolhem a verdadeira libertas, que é a interior, seja porque acumularam dinheiro e compraram um lugar cimeiro na sociedade; é o século em que os donos do mundo matam por prazer e os ricos e poderosos são boçais e falam mal, como o Trimalquião de Petrónio, mas em que outros, como Séneca ou Trásea Peto, enfrentam a morte que lhes é imposta com a serenidade de quem cumpriu a vida e aceita o que o destino traz.

É este o século em que se formam homens de grandes euforias e alguma vaidade, como Plínio-o-Moço, que há-de julgar-se no melhor dos mundos logo que as aparências de mudança o iludirem; mas é também aquele em que surgem homens do mais profundo pessimismo, que vêem a realidade sem máscara e lêem nas rugas do tempo e no mal de outrora a herança fatal a que o presente não foge, como é o caso de Tácito, cuja prosa, especialmente aquela que há-de escrever virado o século, nos prende a cada passo numa rede de desencanto. É uma época em que homens, como Juvenal, vivem acumulando o amargor que, mais tarde, há-de ressumar na corrosiva descrença dos seus textos, enquanto outros observam implacavelmente o seu semelhante e, sem hesitar na firmeza do traço e da chacota, apontam os podres de uma sociedade que conhecem como ninguém, porque nela vivem e a amam, como fez Marcial.

É o século dos astrólogos e da magia, século sem limites em que os escritores não invocam a inspiração de Apolo e das Musas mas o apoio do princeps e dos que dele recebem as migalhas do poder; é um século de cepticismo e de valores materiais, tempo sem deuses em que o culto se presta a Roma e Augusto. Mas é também o tempo em que uma crença não fugaz ganha raízes no coração dos homens, quer essa crença se traduza no desejo de um mundo melhor, em que os escravos são vistos como seres humanos e a vida é dever de aperfeiçoamento constante e de exemplo para os outros, quer se expresse numa ânsia empenhada em tudo saber e conhecer, quer se manifeste em adesão aos mistérios e aos cultos que prometiam uma dimensão de vida para além da morte, quer, ainda, se revele em fé nos ensinamentos do "suave Jesus das searas da Galileia", ${ }^{3}$ Aquele que, no meio de uma densa

3 José Régio, Confissão dum Homem Religioso. Lisboa, Imprensa Nacional Casa da Moeda, 2001 ('1971), p. 115. 
multidão, soube que uma mulher precisava de ajuda por um tímido toque na fímbria do Seu manto. ${ }^{4}$

É este, pois, o século em que, quanto a mim, germinam, de forma mais evidente e fecunda, as sementes, os paradoxos e as certezas, os apelos e as renúncias, a grandeza e a miséria do tempo que se seguiu, e, em última instância, se vincou o perfil dos homens que hoje somos. Ora, sob esse aspecto, a obra de Petrónio é exemplar, pois documenta, em jeito de poliedro, todas as linhas-de-força desse tempo prenhe de contradições e promessas. Nada admira que seja a literatura, como quase sempre, a revelar-se espelho do presente e alfobre do futuro.

Sem querer abordar nenhum dos problemas que engrossam a 'questão petroniana', direi que aceito que o Satiricon data do principado de Nero e que o Petrónio de Tácito é o mesmo que escreveu o primeiro romance da literatura ocidental. ${ }^{5}$ Não discutirei, pois, o ordinal 'primeiro', ainda que não desconheça a teoria sustentada por papiros e novas 'histórias' romanescas analisadas ao longo do século passado. Também não discuto a designação do género, 'romance', que, é sabido, nem sequer existia na teorização literária antiga. Mas nós, que tanto ganhámos com as perspectivas da narratologia, podemos sem medo chamar-lhe o que ele é. Outra coisa será se quisermos dizer porque o é. Mas não é isso o que farei, tanto mais que, entre tantos especialistas do romance, não me atrevo a incorrer na ira de ninguém, nem pretendo arriscar-me a sofrer um qualquer castigo que me obrigue, por exemplo, a percorrer algum labirinto de bibliotecas a refazer o trabalho de casa. Por fim, também não discutirei as origens do romance, nem os géneros e as fontes a que Petrónio foi beber. Aceitemos que se lhe aplique a metáfora 'caleidoscópio', ${ }^{6}$ pois hauriu temas e técnicas na sátira - a romana, em hexâmetros, e a menipeia - nas fábulas Milésias, nas primeiras narrativas romanescas gregas, na comédia nova e no mimo, na poesia elegíaca e na épica, ${ }^{7}$ género que,

${ }^{4}$ Mt 9, 20-22; Mc 5, 25-34; Lc 8, 43-48.

${ }^{5}$ Poderíamos dizer, com René Martin (Le Satyricon. Pétrone. Paris, Ellipses, 1999), que se trata «du premier roman 'moderne'» (p. 170), texto 'fundador' que é «l'archétype du genre romanesque» (p. 113).

${ }^{6}$ Cf. Catherine Connors, Petronius the Poet. Verse and Literary Tradition in the 'Satyricon'. Cambridge, University Press, 1998, p. 43.

${ }^{7}$ Recordemos o que Ben Edwin Perry (The Ancient Romances. A LiteraryHistorical Account of Their Origins. Berkeley - Los Angeles, University of California Press, 1967, p. 206) diz terem sido, para Petrónio, todas essas 'fontes': «these for him were simply building materials». 
mais que todos os outros, des-constrói, transfigura e parodia, num processo genial que hoje, talvez mais do que nunca, suscita admiração.

Vai longa a praeteritio. ${ }^{8}$ É tempo de abordar o tema que me foi proposto. Resumo-o em duas questões: Que reflexo da época encontramos no Satíricon? Para quem foi escrita essa fabulosa narrativa?

Lembremos que, embora as linhas definidoras da literatura do principado de Nero sejam as mesmas do tempo de Tibério, Calígula e Cláudio, as características da faixa cronológica que vai dos anos 54 a 68 , os que medeiam entre a ascensão de Nero ao poder e a sua morte, justificam alguma autonomia de análise. Em primeiro lugar, as condições políticas são diferentes, pelo menos durante o chamado quinquennium Neronis, o período durante o qual Séneca e Afrânio Burro conseguiram manter sobre o princeps o ascendente suficiente para, indirectamente, orientarem os destinos de Roma. Ao senado, Nero devolve grande parte das prerrogativas que entretanto ele perdera, e dá, a princípio, mostras de querer respeitá-lo como não haviam feito os seus antecessores. Assim, com a paz, a prosperidade e a ilusão, que era a de muitos, de que no poder estava o monarca ideal, as condições para um novo 'pico' cultural, o primeiro desde a época augustana, estavam criadas.

Surgem, neste contexto, novos patronos, diferentes de Mecenas, Messala ou Asínio Polião, mas nem por isso menos empenhados em proteger e incentivar a criação literária: em torno de Calpúrnio Pisão, o conspirador de 65, parece ter-se formado um círculo de escritores, entre os quais se contaria o autor do De Laude Pisonis; Séneca, segundo o testemunho de Marcial, que junto dele encontrou protecção quando deixou a Hispania natal para tentar a sorte em Roma, era patrono interessado e generoso. ${ }^{9}$

No entanto, de um modo geral, o papel reservado à cultura resultou, no melhor e no pior, do entendimento que Nero dela tinha: se, por um lado, apoiava e incentivava a criação literária, ${ }^{10}$ tomando medidas que facilitaram o seu florescimento, por outro a sua megalomania

${ }^{8}$ Para um balanço destas perspectivas e respectiva bibliografia: "Introduction: Twentieth-Century Scholarship on the Roman Novel", cap. inicial de S. J. Harrison, editor de Oxford Readings in the Roman Novel. Oxford, University Press, 1999; E. L. Bowie - S. J. Harrison, "The Romance of the Novel": JRS 83 (1993) 159-78.

${ }^{9} 4.40 .1-2 ; 12.36 .8$.

${ }^{10} \mathrm{O}$ próprio Nero reunia na sua corte um círculo de poetas que ainda não haviam adquirido renome. Segundo Tácito (Ann. 14.16.1), eles 'cerziam' e completavam os ensaios poéticos do princeps. 
parece tê-lo levado a não querer que ninguém se distinguisse mais do que ele nos campos em que se considerava artista divinamente inspirado. " Temos, assim, e apenas como exemplo de um aspecto em que essas duas linhas antagónicas coexistiram, a instituição dos Neronia, jogos de modelo grego realizados pela primeira vez em 60 , e que compreendiam, entre outras, provas de música, poesia e eloquência, mas em que todos os consabidos excessos do imperador tiveram oportunidade de se manifestar.

Artista auto-identificado com Apolo, citaredo e actor em papéis como Cânace em trabalho de parto, Orestes matricida, Édipo castigando-se com a cegueira, Hércules enlouquecido, ${ }^{12}$ poeta de que (infelizmente) não restam mais que curtos fragmentos, Nero não pode senão ter contribuido para um movimento artístico que traduzisse os seus ideais estéticos e a sua política cultural. Ora, se alguns o seguiam por constrangimento ou adulação, outros, como aconteceu a princípio com Lucano, talvez o fizessem por adesão sincera ao programa ideológico e artístico do princeps; mas, dos Romanos que se pautavam pela grauitas, a maioria jamais perdoou ao senhor do mundo que se comportasse como alguém marcado de infamia. ${ }^{13}$

Em 62, todavia, com a morte de Burro e o afastamento de Séneca, com a ascensão de Tigelino e Popeia a adjuvantes dos excessos e crimes de Nero, uma época de terror e perseguição inscreve-se no quotidiano de Roma. Ao ler os relatos da Antiguidade (esquecendo embora o que neles pode haver de desvirtuado pela perspectiva censória de quem os escreveu), bem pensamos ser de (um) Nero que fala W. H. Auden, no seu 'Epitaph on a Tyrant', escrito nas vésperas da $2^{\mathrm{a}}$ guerra mundial: «When he laughed, respectable senators burst with laughter, / And when he cried the little children died in the streets.» De facto, e embora alguns, sobretudo os estóicos, se oponham frontalmente ao

${ }^{11}$ Veja-se o que diz Tácito, nos Annales, sobre a 'inveja' de Nero e as suas consequências relativamente a Séneca (14.52.3), Lucano (15.49. 3), o retor Vergínio Flavo (15. 71. 4) e o poeta Cúrcio Montano (16. 29. 2). Também Plínio-o-Moço nos informa sobre o género de obras a que seu tio teve de se restringir, durante os últimos anos de Nero (Ep. 3. 5. 5: «'Dubii sermonis octo': scripsit sub Nerone nouissimis annis, cum omne studiorum genus paulo liberius et erectius periculosum seruitus fecisset»).

${ }^{12}$ Suet., Nero 21. 5; D.C. 62. 9. 4; 10. 2; 63. 22. 6. A coincidência de alguns desses papéis com os seus crimes reais - como o assassinio da mãe - valeram-lhe, como é sabido, graffiti e 'panfletos' anónimos espalhados pela cidade (cf. Suet., Nero 38. 3).

${ }^{13}$ Recorde-se, porém, que foi essa faceta, a dos ludi em que participava e a dos uitia de carácter que pouco a pouco foi revelando, que lhe garantiu o apoio da plebe, a aura popularis que o fez ser tão chorado quando morreu. 
imperador, e paguem por isso com a vida ou o exílio, o medo paralisa uns e empurra outros para a conivência, ainda que passiva e silenciosa, enquanto a cobiça e a falta de escrúpulos embalam muitos outros em encómios interesseiros ou na abjecta delação.

É neste principado, atravessado pelo que há de melhor - a inteligência, a cultura e a dignidade de alguns - e o que há de pior - a crueldade e o desrespeito pela vida humana de muitos outros, que se inscreve naturalmente uma literatura por alguns dita 'pré-romântica', evolução ou confirmação das tendências anteriores, agora marcadas também pela incerteza perante o dia de amanhã e a necessidade de, em algum lugar ou alguma coisa, encontrar um sentido para a existência humana, quer seja na rectidão da consciência, quer em alguma religião ou doutrina filosófica que prometa a salvação ou ajude os homens a trilhar o caminho que conduz à felicidade.

Sente-se assim cada vez mais a presença das religiões mistéricas, esvaziada de sentido que há muito estava a religião tradicional, nem sequer substituída, no coração dos homens, pela religião de Estado, a do culto imperial. $\mathrm{O}$ monoteísmo apaga, numa fé mais íntima, todo o panteão, incluindo o homem que se diz deus vivo, o imperador. O cristianismo, já distinto do judaísmo aos olhos de todos, como prova o castigo a que os cristãos foram sujeitos por Nero na sequência do incêndio de Roma em 64, toca, lenta mas indelevelmente, as mais diversas camadas da população. Mas é o estoicismo que, nesta época, mais importância assume como doutrina capaz de apaziguar a inquietação, como regra de vida que ensina cada ser humano a não ceder ao medo nem a nenhuma outra paixão, e ao mesmo tempo lhe mostra que a sua própria consciência é o único juiz que deve tẻmer, e que a verdadeira felicidade está no exercício da uirtus.

Num tempo de terror, é o estoicismo que ensina a não recear a morte e a buscá-la quando os obstáculos à vida com dignidade forem intransponíveis; numa sociedade em que o escravo é res, é o estoicismo que faz olhar para os servos como homines, em tudo iguais aos que nascem livres; num mundo onde, num segundo, se pode estar a ferros ou a caminho do exílio, é o estoicismo que mostra que só os affectus prendem, que a única servidão é a daqueles que se deixam vencer pelos uitia, que a pátria não é o lugar onde se está mas o mundo todo, que a vida só é breve se dela se fizer um uso errado.

No entanto, na incerteza do amanhã e perante a maior de todas as certezas, a da finitude humana e da fugacidade da vida e da juventude, muitos são também os que se refugiam num culto único ao tudo que cada momento pode trazer, e ao nada que dele fica, quando passa. Com 
mais ou menos consciência das opções epicuristas, mais ou menos transgressão dos limites morais, cala-se o medo e ilude-se a angústia pondo em prática o que Horácio dizia: «Rapiamus, amici, / occasionem de die, dumque uirent genua / et decet, obducta soluatur fronte senectus» (Epod. 13. 3-5).

$\mathrm{Na}$ literatura, todas estas forças se revelam, quer no estilo, o da mais perfeita expressão do asianismo, quer nos temas escolhidos, quer também na intersecção de géneros e na mistura de modelos, ${ }^{14}$ dinâmico processo de criação literária particularmente fecundo desde a época augustana e a que não é alheia a composição do Satíricon. Séneca deixa uma vasta obra de parénese estóica, seja quando escreve Diálogos ou Epistolas, só por topos dirigidos a um destinatário concreto, seja quando compõe tragédias, cujo fim protréptico não diminui o valor literário. Nas sátiras de Pérsio prevalece uma intransigente atitude moral, a de um jovem de estrita obediência estóica. Lucano, depois de incorrer na animosidade de Nero, coloca-se ao lado dos que o criticam, ainda que sob a forma da condenação de César, e da exaltação de Pompeio e Catão de Útica, os verdadeiros heróis do seu Bellum Ciuile.

O individualismo acentua-se, como é de esperar: sem grandes causas nem glória nacional que suscite orgulho ou mova entusiasmos, os escritores viram-se sobre si mesmos, ou então sobre a realidade comezinha do quotidiano, que observam e criticam, abrindo o filão do romance e engrossando o da sátira e do epigrama. Ocupam-se na divulgação da ciência e da técnica, são filólogos, gramáticos, eruditos enciclopédicos, como Plínio-o-Velho. Outros, como Calpúrnio Sículo, talvez acreditem que a Idade de Ouro está de volta com o jovem princeps, mas logo a bucólica se revela, não o género da Arcádia e de Vergílio, mas o da Roma em que o momento de maior fulgor, na vida de quem nada tem, não é mais que entrever, fugazmente e de longe, o rosto de Nero num anfiteatro apinhado (Buc. 7.79 ss.).

Faltam-nos, não o esqueçamos, os escritores que a lei cruel de Nero baniu, e os que depois foram, também eles, atingidos pela damnatio memoriae do último imperador com sangue de Augusto. Não temos os Commentarii de Agripina, as memórias da imperatriz que Tácito ainda consultou. Não temos a obra de Domício Corbulão, sobre as suas campanhas militares contra os Partos e as regiões por onde

${ }^{14}$ V. Paolo Fedeli, "Le Intersezioni dei Generi e dei Modelli”, in G. Cavallo, P. Fedeli, A. Giardina (eds.), Lo Spazio Letterario di Roma Antica. Roma, Salerno Editrice, 1989.Vol. I: La Produzione del Testo, pp. 375-97. 
andou. Não temos as obras de historiadores como Clúvio Rufo e Fábio Rústico, fontes privilegiadas de Tácito, nem a obra histórica de Plínioo-Velho. ${ }^{15}$ Também não temos a 'literatura de oposição', como os versos de Cúrcio Montano ou de Antístio Sosiano, ${ }^{16}$ nem a Vida de Catão de Útica escrita por Trásea Peto, fonte de Tácito e modelo de outras biografias das vítimas da tirania de Nero e, mais tarde, de Domiciano, exemplo do género literário dos exitus illustrium uirorum. Por outro lado, sabemos que, no tempo dos Flávios, a história foi 'reescrita ${ }^{17} \mathrm{e}$, por isso, não chegaram até nós os textos que divulgavam uma imagem benévola de Nero. Não podemos, assim, tirar a bissectriz e, na ausência dessa 'outra versão', resta-nos analisar o testemunho desfavorável de Tácito, Suetónio e Dion Cássio, ${ }^{18}$ aquele em que se fundamentou o juízo crítico da posteridade e lhe deu fecunda matéria romanesca.

Em Petrónio, porém, em cada página do Satíricon, tão vago em alusões históricas $^{19}$ - o que, como se sabe, constitui entrave a uma datação rigorosa da obra - encontra-se abundante reflexo da época, das suas estruturas socioeconómicas e instituições, do modo como os homens viviam o quotidiano e se relacionavam entre si; toda as personagens, todos os episódios são reveladores de um mundo em completa subversão do mos maiorum, dos valores que outrora fundamentavam a grandeza de Roma. Em vez do colectivo, do heróico, do mítico, vigora $o$ individual, o quotidiano, a preocupação com o imediato e o mate-

${ }^{15}$ Referimo-nos, concretamente, ao A fine Aufidi Bassi.

${ }^{16}$ O crime (Tac., Ann. 14. 48. 1: «probrosa aduersus principem carmina factitauit uulgauitque celebri conuiuio, dum apud Ostorium Scapulam epulatur») motivou que, pela primeira vez no tempo de Nero e desde a sua abolição por Cláudio, no ano 51 , se recorresse à acusação de maiestas, por difamação do imperador. Trásea Peto, intervindo a favor de uma pena mais leve (o que contribuiu para a sua própria desgraça), conseguiu que apenas o condenassem à relegatio e confiscação de bens.

${ }_{17}^{17}$ Cf. J., AJ 20. 154; Mart. 3. 20. 4.

${ }^{18}$ Ou melhor: o que, da sua História, subsistiu sobre o principado de Nero nos epitomistas Zonaras e Xifilino.

${ }_{19}$ Algumas delas talvez não passem de 'trouvailles' dos críticos. Pode ser o caso, e.g., da possivel alusão jocosa (128) ao tesouro enterrado de Dido, cuja localização um dos próximos de Nero disse ter-lhe sido revelada em sonhos: tal motivou uma 'campanha' infrutifera para o reaver, gastos astronómicos do princeps por conta do que ia arrecadar, e o suicídio do imprudente sonhador. Cf. Tac., Ann. 16. 1-3. Para o sumário das alusões 'históricas' no Satíricon, v. P. G. Walsh, The Roman Novel. Cambridge, University Press, 1970, pp. 244-7, embora tais dados surjam em outros estudos, nem que seja para fundamentarem uma data posterior de composição. É o caso de R. Martin, "Quelques remarques concernant la date du Satyricon": REL 53 (1976) 182-224. 
rial. ${ }^{20}$ E por isso o Satíricon surge, qual fénix nascida das cinzas do epos. ${ }^{21} \mathrm{O}$ caso mais evidente é, sem dúvida, o de Trimalquião que, segundo ele mesmo diz, de rana se transformou em rex (77. 6), e os seus convidados. O facto de todos serem libertos, de todos, uns mais do que outros, é certo, e pelo menos um deles em franca regressão económica mercê de uns negócios mal calculados, ${ }^{22}$ se entregarem ao comércio ou a profissões e actividades rendosas mas mal vistas pelos Romanos com 'pergaminhos', ${ }^{23}$ retrata de forma soberba um momento histórico, o dos imperadores Júlio-Cláudios, em que se assistiu à ascensão vertiginosa - mas não à inclusão entre o círculo fechado dos bem-nascidos - de um estrato social que assentava o seu poder no dinheiro e fazia de lucrum facere a primeira regra de vida, e de Occupo, epíteto de Mercúrio protector dos ladrões, o mestre reconhecido. ${ }^{24}$ Mas, como resulta de uma sociedade em que a terra é o único bem que deveras enobrece, é natural que Trimalquião, logo que consegue amontoar riqueza suficiente - por meios pouco limpos, que em nada the pesam ou o envergonham - de imediato queira tornar-se latifundiário. Fabulosamente rico, mas estando-lhe vedado ser mais que senir augustalis na sua cidade, ele, que jamais poderá sequer misturar-se com os genuinamente bem colocados na escala social, contenta-se em imitar, ou melhor, em mimar uma esplendorosa farsa do que é, ou

${ }^{20}$ Os valores são agora os consagrados no título do cap. IV de Gian Biagio Conte, The Hidden Author: An Interpretation of Petronius' Satyricon. Berkeley and Los Angeles, University of California Press, 1996, pp. 104-39: "Sex, food and money".

${ }^{21}$ Cf. Paolo Fedeli, "Il romanzo", in G. Cavallo, P. Fedeli, A. Giardina (eds.), op. cit., p. 345: «il romanzo sarebbe sorto sulle ceneri dell' epos». Ou, como escreve C. Connors, op. cit. p. 22: «In the Satyricon, epic is constantly being smashed to pieces and refashioned into fiction before our eyes». Escrevendo sobre a época, R. Martin (in Jacques Gaillard (coord.), Rome I siècle ap. J.-C.. Les orgueilleux défis de l'ordre impérial. Paris, Éditions Autrement, 1996) dá ao seu capitulo (pp. 146-158) o sugestivo título: "Un siècle d'épopée qui accouche d'un roman".

22 Cap. 38. É agora, portanto, um parasita, um dos que procura no jantar oferecido uma forma de se sustentar. É curioso notar, nesta figura, o facto de 'ser duro na queda', ao querer esconder a todo o custo o seu regresso à penúria. Isso, embora todos saibam o que se passou e porque se passou: a culpa não foi verdadeiramente dele, excepto porque confiou em outros libertos, que se orientaram no negócio.

${ }^{23} \mathrm{O}$ 'cursus' de Trimalquião (comércio em larga escala, seguido de aplicação e 'lavagem', diríamos nós - do dinheiro obtido na compra de terras) é excelente ilustração do que Cícero propunha em Off. 1.41.

${ }^{24}$ 58. 12 (lucrum faciam); 70. 1 (crescam patrimonio); 58. 11 (Occuponem propitium). Esta mentalidade traduz-se também na certeza de Trimalquião em que «Nemini ... nihil satis est» (76. 3) e em que 'riqueza gera riqueza' (77. 6: «habes, habeberis»). É interessante verificar que, no pavimento de uma casa romana, se podia ler a inscrição Lucrum gaudium (CIL X 875). 
ele julga que é, fino e requintado. Ora, anfitrião, mulher de anfitrião e convivas, todos eles são vistos pela perspectiva de Encólpio, que é, como se sabe, um jovem de berço e boa educação que se meteu por caminhos ínvios, mas não perdeu a 'pose' nem os preconceitos: e esse artifício da composição permite que eles se revelem em toda a sua boçalidade e divertida ignorância, vistos com sobranceria ou hilaridade, outras vezes com alguma surpresa, mas nunca, por nunca ser, como membros da nata social. O próprio Trimalquião tem consciência da sua marginalidade, da mesma forma que tem plena noção de que, para a sociedade romana, vale pelo dinheiro que tem, ${ }^{25}$ não pelo que é ou o que fez. Esse orgulho, que ele e os outros sentem, no que conseguiram e naquilo em que se tornaram, ${ }^{26}$ essa necessidade de se mostrarem aos que provêm de um mesmo meio, mais não é, como Paul Veyne sublinhou, ${ }^{27}$ que uma espécie de compensação para a impossibilidade de apagar o estigma das origens e para a exclusão a que os verdadeiramente influentes os votavam.

Essa réplica de um estatuto que não é o seu, essa ostentação de mau gosto, mas sempre espectacular, e que não deixa de coincidir com muito do que sabemos, por outras fontes, literárias e arqueológicas, que se passava, quer na Domus Aurea de Nero, quer nas casas de muito boa gente, ${ }^{28}$ representa também o carácter teatral de uma época e de uma forma de viver em sociedade e, até, de fazer política e de governar, como vários estudos já demonstraram. ${ }^{29}$ Dispenso-me, por isso, de desenvolver os inúmeros aspectos em que o Satíricon, todo ele, mas em especial no episódio da Cena, traduz esse mundo de ilusão, esse momento em que todos são, a um tempo, espectadores e actores, inclu-

25 77. 6: «credite mihi: assem habeas, assem ualeas».

${ }^{26}$ É significativo que reconheça: «uirtute mea ad hoc perueni» (75. 8).

27 "Vie de Trimalchion" in La société romaine. Paris, Seuil, 1991, pp. 13-56.

${ }^{28}$ Para dar apenas o exemplo mais flagrante, sabe-se que na Domus Aurea havia cenationes cujo tecto, em marfim, era móvel e tinha orificios pelos quais se lançavam flores e perfumes sobre os convidados, e que a principal dessas salas de banquetes tinha um tecto que girava continuamente, representando o céu (Suet., Nero 31. 3). Compare-se, pois, com o que acontecia em casa de Trimalquião (60).

${ }^{29}$ Remeto tão-só para dois capítulos e um apêndice de Shadi Bartsch, Actors in the Audience. Theatricality and Doublespeak from Nero to Hadrian. Cambridge Mass., Harvard University Press, 1994: "The Emperor's Audience: Nero and the Theatrical Paradigm" (pp. 1-35); “ The Invasion of the Stage: Nero Tragoedus" (pp. 36-62); "The 'Cena Trimalchionis' as Theater" (pp. 197-9); bem como para Gerald N. Sandy, "Scaenica Petroniana": TAPhA 104 (1974) 329-46; Gianpiero Rosati, "Trimalchio on Stage", in S. J. Harrison (ed.), op. cit., pp. 85-104 (trad. de "Trimalchione in scena": Maia 35 (1985) 213-27). 
sive o imperador, em que nada, nem a comida, é o que parece, em que todos os gestos do quotidiano são regulados pelo efeito a conseguir junto dos outros.

Petrónio dá-nos também conta de uma polémica, se assim the podemos chamar, que assumiu grande importância ao longo do séc. I: a que discutia os cânones e os princípios da estética literária. De um lado, os que inovam, do outro, os que seguem a tradição. Dito de outra maneira, de um lado os que pretendem respeitar ou regressar às normas do classicismo augustano, do outro os que experimentam novos caminhos estéticos; ao nível estilístico, estremam-se os campos entre os 'neo-áticos' e os 'neo-asiânicos'. No tempo de Nero, são estes que parecem levar a palma; mas logo um Quintiliano e um Plínio-o-Moço reverterão tal tendência. Ora, como é sabido, é na boca de Eumolpo (118-9) que são postas as premissas que defendem o classicismo, de um Horácio e de um Vergílio, na literatura, mas também nas artes plásticas; e não é sem dúvida por acaso que esse mesmo Eumolpo diz uma coisa mas faz outra, quer do ponto de vista estilístico, quer também quando vocifera contra a imoralidade dos tempos logo após contar a sua aventura erótica com o menino de Pérgamo $(85-87 ; 88)$.

O 'Bom Cantor' serve também a Petrónio para levantar a questão da escolha de temas e géneros. A épica de Lucano, como é sabido, representa um modo diferente de conceber o epos, sem deuses a intervir no curso dos acontecimentos ou a reger a vida dos humanos. Só o Fatum e a Fortuna, só o determinismo estóico regulam as acções e o devir histórico. Essa nova forma de entender a épica, que diverge do cânon vergiliano, insere-se na tendência de mudança já atrás referida, mas resulta também de uma resposta ao esvaziamento de certos géneros e temas, sobretudo os mitológicos, causa do cansaço de que o público e os leitores de poemas épicos e tragédias amiúde davam provas. Basta lembrar o que diz Marcial sobre os poetas que insistem em compor épicas e tragédias de assunto mitológico que ninguém lê nem aprecia ${ }^{30}$ circunstância a que se junta o facto de muitos dos episódios trágicos e épicos, aqueles que mais agradavam ao público, se terem transformado em pantomimas, género teatral que, desde o fim da República, vinha ocupando o espaço da tragédia. ${ }^{31}$ Não parece, pois,

${ }^{30} 4.49 ; 5.53 ; 8.3 .13$ ss.; 10. 4. Ver também Juv. 1. 1-17; 52, e a sua referência a Rubreno Lapa, autor de um Atreu que, talvez não por acaso, the valeu apenas a pobreza (7. 72-73).

${ }^{31}$ Um dos que parece ter tido mais favor foi o dos amores de Dido e Eneias, como provam as afirmações de Luciano (Salt. 46) e Macróbio (5. 17. 5). 
ser por acaso que Eumolpo é apedrejado quando canta a Troiae Halosis, ${ }^{32}$ que suscita o desagrado de todos, ${ }^{33}$ mas colhe o assentimento e prende a atenção unânime dos que o ouvem contar o episódio da Viúva de Éfeso (111-113. 1). Além disso, Eumolpo encarna a figura do poeta que vive nas franjas da sociedade, sem que lhe reconheçam o valor e importância, qual Marcial que, anos depois, se queixa de ser menos conhecido que o cavalo Andrémon, ${ }^{34}$ e de ter de se esfalfar um dia inteiro para ganhar a miséria da sportula, enquanto o auriga Escorpo arrecada «numa hora / quinze pesados sacos de ouro ainda rebrilhantes». ${ }^{35}$ Os ídolos do povo não são os homens da cultura: são os pantomimos, os gladiadores, os cocheiros das factiones Azuis ou Verdes.

Outra polémica encontra também eco no Satíricon: a decadência da oratória e, a um tempo causa e consequência dessa ruína, a inanidade dos curricula pedagógicos - passe o anacronismo - em Roma. Todos nos lembramos da tirada inicial de Encólpio contra os temas tratados nas escolas de retórica, desligados da vida, cheios de vãs palavras e magros de ideias. ${ }^{36}$ Todos sabemos também que o assunto mereceu a atenção de Séneca Pai, em prefácios aos livros das Controuersiae, e, mais tarde, de Tácito, no De Oratoribus, e de Quintiliano, no perdido De causis corruptae eloquentiae. Esse quase lugar-comum da reflexão sobre o declínio da oratória, que tem em Agamémnon o repre-

${ }^{32}$ Tal como sobre o Bellum Ciuile, também sobre este poema não entrarei na uexata quaestio de quem terá Petrónio querido imitar ou parodiar.

${ }^{33} 90.1$. É de resto o que, como ele próprio confessa, the acontece sempre que entra num teatro para recitare $(90.5)$. O apontamento remete, por isso, para outro 'ponto quente' do momento: o descrédito das recitationes, que provocavam náusea, enfado ou indiferença em quase todos.

${ }^{34}$ 10. 9. 5. V. tb. 3. 38. 9-10. Mas o epigrama que melhor traduz a ingratidão com que são tratados os poetas, mesmo aqueles a quem se reconhece valor, é 6. 82, onde a pergunta «Cur ergo (...) habes malas lacernas?» (v. 9) e a resposta «quia sum malus poetan (v. 10) parecem eco das palavras de Eumolpo, quando pela primeira vez fala a Encólpio: «Ego (...) poeta sum. (...) Quare ergo, inquis, tam male uestitus es? Propter hoc ipsum» (83. 8-9).

35 10. 74. 5-6. Tradução de Paulo Sérgio Ferreira (Marcial, Epigramas. Vol. IV. Lisboa, Edições 70, 2004). V. também 10. 76, em que se fala de Mévio, «cujo único / defeito - bem grande por sinal - é o ser poeta» e «que tirita em negra capa, / enquanto de púrpura refulge o cocheiro Incitato».

${ }^{36} \mathrm{E}$ da chacota de Trimalquião, pedindo a Agamémnon a peristasis (note-se o requinte do termo técnico!) da sua declamatio. Mordendo a isca, o retor responde: «Pauper et diues inimici erant», o que suscita a 'gracinha' do liberto: «Quid est pauper?», mas não impede que a controuersia seja apresentada e criticada pelo anfitriào (48. 5). 
sentante dos mestres que não saíam das escolas nem experimentavam as lutas dos tribunais ou do senado, e em Encólpio o resultado prático dessa formação, era, pois, tema candente de uma época em que se propunha aos jovens a glória máxima das declamationes. Ora, na resposta a Encólpio, Agamémnon demonstra que, tal como Eumolpo, pensa e diz uma coisa, mas faz outra, alijando a culpa de ensinar frivolidades para cima dos alunos e respectivos pais, mais empenhados em seguir a moda do que em estruturar a mente e apetrechar a bagagem do conhecimento.

Contrariando de certo modo essa apetência pelo vulgar e imediato, pelo que embriaga os sentidos, embotando a inteligência, e sem nele vislumbrarmos qualquer mensagem ou função moralizante, ${ }^{37}$ mas antes uma intenção lúdica no retrato - umas vezes realista, outras vezes em traço de caricatura - da sociedade em colapso da segunda metade do séc. I, o texto do Satíricon pressupõe uma elite de leitores cultos, refinados, capazes de entender alusões, decifrar códigos, reconhecer modelos parodiados, interpretar o sentido e saborear a ironia dessa paródia, quer ela se reporte a géneros, quer a obras ou autores específi$\cos ^{38}$ De facto, só um leitor de Séneca se apercebia do efeito conseguido pelas inúmeras sententiae que consagram, em jeito lapidar, autênticas banalidades, postas na boca das personagens petronianas, e que não só retomam um dos recursos mais característicos do estilo do filósofo, mas também evocam, em gritante contradição com o modo de ser e agir dessas personagens, alguns dos temas mais caros da reflexão estóica, como a meditatio mortis, a crítica aos excessos ou a degradação dos costumes. Também só um conhecimento da perspectiva de Séneca sobre os escravos - e a consciência de que, de facto, as mentalidades estavam lentamente a mudar ${ }^{39}$ - permitiria apreciar a alusão do

${ }^{37}$ Talvez nem sequer politica, pese embora a pertinência da análise de, e.g., Vasily Rudich, no cap. "Petronius: The immoral immoralist" (pp. 186-254) in Dissidence and Literature under Nero. The Price of Rhetoricization. London, Routledge, 1997. Para uma hipótese de leitura de moralidade no romance, v. Delfim Ferreira Leão, As Ironias da Fortuna. Sátira e Moralidade no Satyricon de Petrónio. Lisboa, Colibri, 1998.

${ }^{38} \mathrm{O}$ que corresponderia a um «typical Graeco-Roman pleasure in the recognition of allusions; and further amusement from the radically changed context» (J. P. Sullivan, "Petronius' 'Satyricon' and its Neronian Context" in ANRW II 32, 3 , p. 1683, texto que retoma Literature and Politics in the Age of Nero. Ithaca N.Y., Cornell University Press, 1985, p. 175).

39) Disso dá mostras, sem dúvida, a reacção popular à condenação à morte de todos os escravos do praefectus Vrbis Pedânio Secundo, assassinado por um só de entre eles no ano 61. Tal condenação, prevista na lei em vigor, foi violentamente 
cap. 71 ao tema e ao texto da Epist. 47, bem como a atitude de Trimalquião fazendo sentar à mesa os servos, para enfado dos convidados (70. 10). Só quem conhecesse o código elegíaco e a poesia de Propércio e Ovídio se daria conta do eco desses poetas nos hendecassílabos (79. 8) que Encólpio, jubiloso, entoa após uma noite inesquecível com Gíton, tal como só um leitor da lliada se deleitaria com a reacção do mesmo Encólpio, trancado num quarto durante três dias a remoer a sua dor por se ver privado do amado puer (81), qual Aquiles consumido com a perda de Briseida. Só os leitores do Banquete de Platão poderiam reconhecer na chegada de Habinas à Cena o eco paródico da entrada de Alcibíades, ou fruir o contraste entre as intervenções dos convivas do diálogo grego e as falas dos libertos que rodeiam Trimalquião, figura 'degradada' do simposiarca, que disserta sobre os mais variados temas. ${ }^{40}$ Mas também apenas alguém atento à realidade histórica poderia descortinar - e aqui entramos no terreno movediço das hipóteses - no gesto magnânimo de Trimalquião, quando autoriza, ou melhor, quando incentiva os seus convidados a não reterem os gases, porque fazem mal, uma alusão a um edicto que Cláudio quase promulgara nesse sentido ${ }^{41}$, tal como só um leitor oriundo de um estrato social elevado e senhor de apurada educação poderia, com a inteligência e o humor que apenas essa inteligência consente, detectar e divertir-se com as inúmeras transgressões à etiqueta e às boas maneiras de Trimalquião e os que o rodeavam, bem como com os solecismos e barbaridades culturais com que todos, mas em especial o anfitrião da cena, revelavam o verniz que depressa estala e mostra a verdadeira face da gentinha que veio do nada. Por fim, e para evocar apenas dois dos mais estimulantes exemplos dessa leitura 'decifrada', só um conhecedor

contestada pelas ruas de Roma e a discussão chegou mesmo ao senado, onde, embora sem êxito, houve quem falasse contra a injustiça do suplício de tantos inocentes. V. Tac., Ann. 14. 42-45.

${ }^{40}$ Cf. Florence Dupont, Le Plaisir et la Loi. Du 'Banquet' de Platon au 'Satiricon'. Paris, Maspero, 1977, passim; e A. Cameron, "Petronius and Plato": CQ n.s. 19 (1969) 367-70; F. Bessone, "Discorsi dei liberti e parodia del Simposio platonico nella Cena Trimalchionis": MD 30 (1993) 63-86, artigos que não pude, todavia, consultar. Sobre a paródia, em geral, no romance, v. Paulo Sérgio Margarido Ferreira, Os Elementos Paródicos no Satyricon de Petrónio e o seu Significado. Lisboa, Colibri, 2000.

41 47. 1-6; Suet., Cl. 32. 5. De igual modo, só um frequentador dos ambientes mais requintados poderia entender a alusão ao inauditus mos que Encólpio tanto estranha: o perfumar dos pés durante a cena (70. 8). De facto, Plínio (Nat. 13. 22) diz que foi Otão a introduzir esse costume na corte de Nero. Trimalquião está, pois, na vanguarda da moda... 
profundo da Eneida poderia apreciar o alcance do travestimento de Dido em Matrona de Éfeso e de Eneias em miles que, trazendo-lhe comida e amor, conduz a viúva não à morte, mas à vida; só esse leitor teria ainda o poder de soltar uma gargalhada com a dessacralização desse hipotexto, ${ }^{42}$ no célebre centão de passos vergilianos (132.11) em que Encólpio se dirige ao seu membro flácido, que não lhe responde, tal como Dido não respondeu a Eneias nos Infernos, e que, como Euríalo, tomba sem vida, qual papoila colhida pelo arado. ${ }^{43}$

À distância de quase dois mil anos, fica-nos a certeza de que nunca será possível descortinar todas as chaves de leitura do Satiri$\operatorname{con}^{44}$ nem sequer decifrar muitas das alusões que até aos contemporâneos poderiam passar despercebidas. Não é isso, porém, nem mesmo o estado fragmentário em que a obra chegou até nós, que faz com que ela exerça um fascínio menos envolvente que nos leva a percorrê-la, como um labirinto de que não se pode nem se quer sair. ${ }^{45}$ Um fascínio que se estende à figura de Petrónio, o Petrónio de Tácito, indissociável do Satíricon. Não admira, pois, que, de quando em vez, escritores e cineastas neles busquem matéria de criação artística. Seja quando inventam, como Marcel Schwob em Vies Imaginaires, ${ }^{46}$ uma biografia de Petrónio, que não se suicida e parte com um escravo para viver as aventuras que escrevera, seja quando colocam um Des Esseintes, rico e decadente, a explicar porque era Petrónio "L'auteur qu'il aimait vraiment", como fez Joris-Karl Huysmans no A rebours (1884), seja quando concebem "um Satyricon moderno", como Pier Paolo Pasolini

${ }^{42}$ É sabido e provado que «Su Petronio (...) agiscono costantemente due ipotesti, l'Odissea e l'Eneide, nei cui confronti il Satyricon si configura come ipertesto.» (Paolo Fedeli, "Il romanzo", in G. Cavallo, P. Fedeli, A. Giardina (eds.), op. cit., p. 364).

43 A paródia vergiliana é particularmente significativa também nos versos sotádicos de 132. 8. Como diz C. Connors, op. cit., p. 31, «The triple attempt [do impotente Encólpio] at castration mimics heroic triple attempts to embrace the shades of the beloved dead», por evocação de Aen. 2. 791-93; 6. 700-1.

${ }^{44}$ Pela riqueza e pertinência da análise, v. a dissertação de doutoramento de Cláudia Teixeira, Estrutura da Viagem na Épica de Virgilio e no Romance Latino, apresentada à Universidade de Évora em 2003, que esperamos seja publicada em breve.

${ }^{45}$ Sobre o «noui generis labyrinthus» (cf. 73. 1) que encontramos em vários episódios do romance (a Graeca urbs, o lupanar, a casa de Trimalquião, o barco de Licas...), v. Paolo Fedeli, "Petronio: il viaggio, il labirinto": MD 6 (1981) 91-117 e "Il romanzo", in Lo Spazio..., pp. 353-6.

${ }^{46}$ Publicado em 1896. Há tradução portuguesa, mas de tão má qualidade que faço questão de não a citar. 
no monumental Petrolio, ${ }^{47}$ seja, ainda, e para lembrar aquele que penso ser o mais recente testemunho dessa pervivência, quando reinventam um fresco onde fervilham «tous les vices et bien les vertus trop ostentatoires des faux culs de cette époque, qui peut, par certains côtés, renvoyer à la nôtre», como acontece no romance de Pierre Combescot, Ce soir on soupe chez Pétrone. ${ }^{48}$

${ }^{47}$ Editado em 1992, dezassete anos após o assassinato de Pasolini, que o deixou incompleto. Há tradução portuguesa, de José Colaço Barreiros (Petróleo, Ed. Notícias, 1996; Planeta DeAgostini, 2002). Sobre o paralelo com Petrónio, v. Massimo Fusillo, "From Petronius to Petrolio" in S. Panayotakis, M. Zimmerman, W. Keulen (eds.), The Ancient Novel and Beyond. Leiden, Brill, 2003, pp. 413-23.

${ }^{48}$ Paris, Grasset, 2004. Evidentemente, a esta enumeração não preside nenhum critério de exaustividade, que seria impraticável. Omito, entre outros, o famoso Quo vadis? de Henryk Sienkiewicz (1895), e, no cinema, o Satiricon de Fellini. Sobre a Nachleben do texto de Petrónio, leia-se, por isso, P. G. Walsh, op. cit., pp. 224-43, e R. Martin, Le Satyricon ..., pp. 78-127. 